\title{
Professionalism in GIS: International Aspects of the Certification Debate
}

\author{
Galcano Canny Mulaku \\ Department of Geospatial and Space Technology (Formerly Surveying), School of Engineering, \\ University of Nairobi, Nairobi, Kenya \\ Email: gmulaku@yahoo.com
}

Received April 15, 2013; revised May 15, 2013; accepted June 15, 2013

Copyright (C) 2013 Galcano Canny Mulaku. This is an open access article distributed under the Creative Commons Attribution License, which permits unrestricted use, distribution, and reproduction in any medium, provided the original work is properly cited.

\begin{abstract}
GIS certification has been a contentious issue amongst geo-technology professionals for years. Many arguments have been advanced for it, the chief one being that certification is the only way through which a true GIS professional can be defined for the consumer public. There have been counter arguments, for example that certification will limit the widespread adoption of GIS technology, which is just a tool that anybody should be free to apply, or that it will only add another layer of regulation in a global political environment that favours increased de-regulation. The objective of this paper is to create greater awareness about GIS certification, which doesn't exist yet in many countries, including some developed ones. Such increased awareness may encourage the standardization of GIS personnel qualifications, which could underpin a better, more dependable growth of the GIS industry, especially in the developing countries. Through analysis of key existing literature on the subject, plus the author's own professional experiences, the paper explores the issues around GIS certification, looks at global trends on the issue and discusses the situation in the Kenyan GIS industry in respect of certification. The paper finds that there is a global move towards certification, and the relevant work of ISO has given the issue international attention. However, the paper also finds that the presence of a strong GIS professional association greatly assists in the development of a program for such certification, and that the lack of such an association makes it difficult to succeed.
\end{abstract}

Keywords: GIS Certification; Professionalism; Standards; Kenya

\section{Introduction}

GIS technology came into the public mainstream, and was first taught in universities in the mid 1980s; indeed, the very first university level text book [1] on the subject was published in 1986. The application of the technology was first as project GIS, in which it was used in the management of large, often public sector projects, and only those on the project would have access to the technology. This evolved into enterprise GIS, in which everyone in a user organization would have access. Today we have community GIS, in which the array of users ranges from top professionals to the average citizen. This wide access to the technology has created a wide array of skill sets that are not easily distinguished by the average professional service seeker. Just like the general IT industry before it, the GIS industry has been showing a clear need for the standardization of these skill sets for better control of the profession.

Research in this area of standardization of GIS skill sets started in the early 1990s, mainly in the USA, from where one of the most successful certification programs has evolved. However, there is as yet no internationally agreed upon certification program and research continues towards harmonizing whatever programs emerge into one that has wide international acceptance; This is important especially in view of global geospatial initiatives such as the Global Spatial Data Infrastructure (GSDI). In addition, very little has been written on such certification in developing countries. This paper, by reviewing the international status of GIS certification and reporting on the situation in Kenya, is a contribution in furtherance of such research.

\section{Definition of Professional Certification}

Professional Certification is a process, often voluntary, through which individuals, who have demonstrated a level of expertise in the profession are identified to the public and the stakeholders by a third party. It differs 
from professional licensure in that the latter is normally carried out by a government, and is legally required in order to practice the profession. Certification, which need not be legally binding or be recognized by all, is normally carried out through national professional associations. It simply signifies that one meets the baseline standards for the profession, as established by an authoritative body recognized by the profession. Certification is therefore designed to recognize expertise, while licensure is designed to guard against incompetence.

Certified professionals, who often use some insignia or designatory letters (e.g. MISK for Member of the Institution of Surveyors of Kenya, FRICS for Fellow of the Royal Institution of Chartered Surveyors, MASPRS for Member of the American Society of Photogrammetry and Remote Sensing, etc.) to distinguish themselves, usually subscribe to a code of professional ethics. Professional ethics are a set of rules that a given group of professionals swear to uphold in the conduct of their affairs. Certification is usually valid for a given period of time, e.g. three to five years, following which the professional must be re-certified by submitting a new portfolio of work and/or work upgrades. The main reason for certification is usually to provide a distinguishing mark of quality for the consumer public that seeks professional services.

\section{The Argument for GIS Certification}

\subsection{GIS: A Multidisciplinary Mix}

The GIS industry, being multidisciplinary (see Figure 1), brings under the same roof an almost unlimited mix of different professionals such as geographers, surveyors, cartographers, computer scientists, geologists, etc. The list expands daily, quite literally. Indeed, while opening the 2009 ESRI International User Conference in San Diego, California, USA, Jack Dangermond, the President of ESRI, stated that, "...GIS is the technology that is working on all the world's challenges such as climate change, agriculture, environment, planning, facility management, etc. It seeks to connect all and might just be the lynchpin for a powerful new global movement... [2]. This multidisciplinary application of GIS is also indicated in a proposed moral ideal for the GIS professional: "To apply geospatial technologies and spatial thinking to design futures for people and places everywhere" [3].

In addition, the use of GIS is not limited to professionals; indeed, the concept of a Spatial Data Infrastructure (SDI) envisages an all pervasive use of the technology that goes right down to the ordinary citizen [4]. One therefore ends up with a diverse mix of players in the industry that have a wide array of educational backgrounds (like they say, some have no degrees, while

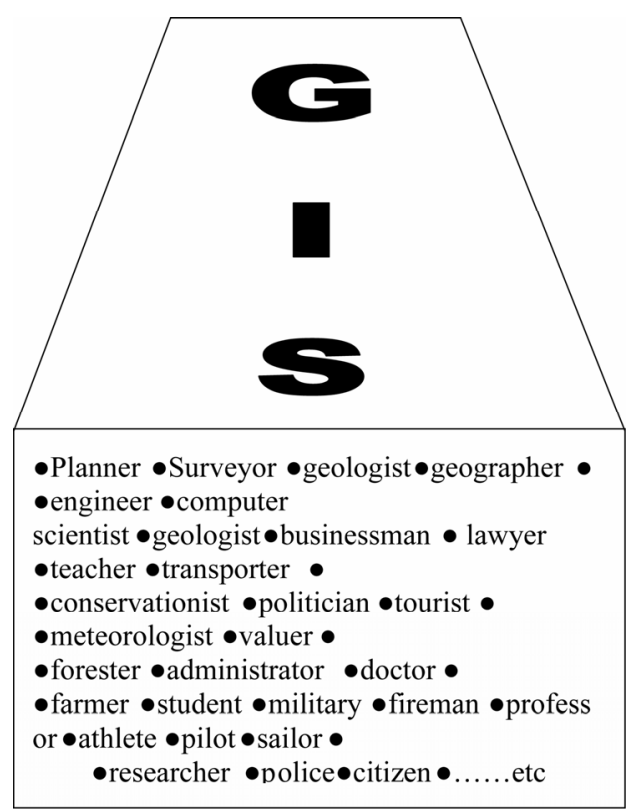

Figure 1. GIS: A multidisciplinary mix of professionals and non-professionals.

some have many degrees) and GIS skills.

\subsection{The Professional Status of GIS}

This question is often asked in view of the fact that many users of GIS, at least at the higher levels, are already certified or licensed in their own professions such as surveying, cartography, geology, etc. The key attributes common to all professions are:

- Skills based on a specialized body of knowledge;

- Advanced academic training;

- A professional association and/or regulatory body;

- Insignia, based on a nationally recognized certification/licensure program;

- A code of ethics;

- International mobility (i.e. cross border recognition of skills).

In many countries, the GIS industry has most of these attributes and hence qualifies to be a profession; For example, recommended skill sets are defined in documents such as the Geospatial Technology Competency Model (GTCM) [5], published by the US Department of Labour, Employment and Training Administration, and it is estimated that advanced academic training in GIS is available in over 7000 universities and colleges worldwide [3]. However, compared with long established professions such as medicine, engineering, surveying or law, the GIS profession is still very young and hence many aspects of its professionalism are still developing; A study [6] found that over $70 \%$ of people in GIS jobs think that GIS should be considered a profession and that GIS certification should be implemented. 


\subsection{The Need for Certification}

The argument for certification is largely rooted in the fact that the professional diversity found in the GIS industry results in a mixed state of perceptions in which a GIS software operator, a statistician, an analyst, a programmer, a project manager, an average user of GIS products - none of whom share the same skill set—might be considered a GIS professional. As a result, job titles, responsibilities and professional expectations become confused and can result in serious misunderstandings and costly mistakes. Even worse, it leaves the consumer public in the dark in respect of who to go to for diverse GIS assignments. To many members of the public, anything coming out of a computer "must be right", and this leaves such a public wide open to manipulation by unqualified people.

Certification would be able to clear much of this confusion by discriminating between the GIS user and the GIS professional. It could do this by codifying good and bad practice, implementing a professional code of ethics that establishes the consequences of bad practice, and outlining the education and work experience necessary to establish good GIS practice.

Specifically, certification is beneficial to:

- GIS Professionals: Certification helps distinguish professionals committed to the GIS profession from casual or inexperienced practitioners. In this way GIS expertise is recognized and promoted and genuine professional alliances built at the local, national and international levels. Certified GIS professionals will also be able to better lobby their governments and other facilitative bodies for resources or representation.

- Employers: Employers can have more confidence in certified GIS professionals, knowing they have met professional benchmarks, demonstrated extensive professional practice, and shown integrity in their work.

- The public: Given that the public sector is one of the largest employment sectors using GIS, tax payers will be assured to know that ethical and proficient GIS professionals are being hired with their tax money, and that certification protects them from quacks.

- GIS students: Students and young practitioners, by knowing about certification and interacting with certified professionals, become aware of what it takes to be a well rounded GIS professional both technically and ethically.

- Allied professionals: As GIS practitioners interact with others from nearly every field, allied practitioners such as planners, surveyors, engineers, etc will have the comfort of knowing that they are dealing with GIS professionals that have undergone profes- sional scrutiny similar to their own.

\subsection{The Challenge of a Certification Standard}

It must be cautioned that in the absence of a national certification standard, certification could be tricky, with many different organizations putting together competing certification programs that are not uniform in terms of scope or level. This could only create more confusion in the industry. The adoption of such a standard will need consensus from GIS stakeholders such as data producers, users, academia, etc. Such stakeholders can be best rallied together by a strong GIS professional association. It was noted in [7] that the demand for GIS certification must come primarily from those who work in the profession. It must be further cautioned that a certification program that includes educational achievement as part of the criteria must necessarily go hand in hand with accreditation of the relevant academic programs. Accreditation means the recognition of an academic program as meeting defined minimum standards in terms of curriculum content, facilities, personnel and equipment [8]. The accreditation of a program expires after a predetermined period of time (often five years) when accreditation must be sought again.

\section{World Trends}

\subsection{General}

The general trend worldwide is to move towards certification. There have been arguments to the effect that GIS certification would interfere with the "tool nature" of the technology and limit its wide applicability. However, one only needs to look at what happened in the general IT industry to see the lack of wisdom in this argument.

For long, practitioners in general IT (Programmers, system analysts, etc.) also resisted certification. However, a "free for all" situation soon developed, where anyone claimed to be anything, and all sorts of IT Colleges sprung up claiming to offer tuition in diverse aspects of IT. Many of the graduates of such colleges were often found wanting when subjected to scrutiny. Consequently, IT policies and legislation had to be developed, and professional associations formed to bring order to the industry. In the United States, where one of the biggest IT industries resides, the US Institute for Certification of Computing Professionals was set up for this purpose [9] and has been a role model for certification programs in the area of geoinformation.

\subsection{The United States}

GIS certification has been discussed and tried since the early 1990s in the US when the American Society for Photogrammetry and Remote Sensing (ASPRS) set up a 
limited certification program for "Mapping Scientists, GIS/LIS” [10,11]. A much more inclusive program has its origins in URISA (Urban and Regional Information Systems Association)'s certification committee that was formed in 1997 [12]. Following much debate, the committee eventually evolved into the GIS Certification Institute (GISCI), which has developed a code of ethics and a portfolio based certification program. The program requires minimum levels of achievement in education, professional experience and contributions to the profession (e.g. participation in conference organization, publications, etc.) in order to certify one as a GIS professional entitled to use the designation "GISP", i.e. GIS professional; This is summarized in Table 1. The first 29 GISPs passed out in 2003 at URISA's annual conference in Atlanta Georgia; They were required to re-submit their portfolios after five years for re-certification. One of those early GISPs was Roger Tomlinson, reputed to be the father of GIS. Up to the end of 2008, there was a grand fathering provision through which older members of the profession could gain GISP status through experience alone; however, this provision was not available for re-certification.

As of March 2013, there were 5241 GISPs around the world, but concentrated in the USA [13].

The basis for the GISP program is that experience is the most important factor in applying skills to real world problems, and education plays a very important role in providing the knowledge and intellectual maturity required to approach problems and communicate solutions effectively. In addition, professionals must contribute to the advancement of the profession by donating their skills in professional activities not designed for individual compensation, but rather to maintain the fundamental health of the profession.
The GISCI is currently (2013) developing an examination component to be added to their certification requirements in about 3 years time. The ESRI Technical Certification Programme, which requires a pass mark in the use of ESRI products is a likely model to guide the development of this component. ESRI technical certification examinations are offered at 2 levels, Associate and Professional, and each level reflects a recommended set of skills, knowledge and experience using ESRI products [14].

The GISP program is recognized by most of the US professional associations dealing with geo-information, such as the American Congress on Surveying \& Mapping (ACSM), American Society for Photogrammetry and Remote Sensing (ASPRS), the Association of American Geographers (AAG) and the University Consortium for Geographic Information Science (UCGIS). The program is also recognized by ESRI, the world market leader in the development and sale of GIS software, which offered free training and materials for the first 1000 GISPs [15].

\subsection{Selected Other Countries}

Table 2 summarizes the GIS certification scenarios in a number of selected countries, outside the USA, with large GIS industries. In all these countries, there is a long standing system of accreditation of surveyors; Since surveyors, due to their strong backgrounds in the spatial sciences, play a key role in any GIS industry, their accreditation systems could be used as suitable models to guide the development of similar systems for GIS professionals.

\subsection{ISO}

The International Organization for Standardization (ISO)

Table 1. The GISCI certification program for GISPs (Source: www.gisci.org).

\begin{tabular}{|c|c|c|}
\hline Benchmark & Requirement & Required Points \\
\hline Educational achievement & $\begin{array}{l}\text { A combination of formal (degree, diploma, } \\
\text { certificate), informal (e.g. short courses) and } \\
\text { conference/workshop experience }\end{array}$ & At least 30 \\
\hline Professional experience & At least 4 years of diverse experience with GIS & At least 60 \\
\hline Professional contribution & $\begin{array}{l}\text { A variety of contributions, such as GIS publications, } \\
\text { GIS awards, GIS professional association involvement, } \\
\text { conference/workshop organization or instruction. }\end{array}$ & At least 8 \\
\hline All the above & $\begin{array}{l}\text { Additional points earned for educational achievement, } \\
\text { professional experience and contribution to the } \\
\text { profession or a combination of them. }\end{array}$ & At least 52 \\
\hline Code of ethics & $\begin{array}{l}\text { Commitment to the GISCI code of ethics } \\
\text { and rules of conduct. }\end{array}$ & $\begin{array}{c}\text { No points but candidate signs a copy of the code. } \\
\text { Violation of the code may result in revocation } \\
\text { or suspension of certification. }\end{array}$ \\
\hline Certification & Points earned from all the above & At least 150 \\
\hline Re-certification & Every five years. & \\
\hline
\end{tabular}


Table 2. GIS certification in selected countries.

\begin{tabular}{|c|c|c|}
\hline Country & $\begin{array}{l}\text { GIS professional association or } \\
\text { nearest equivalent }\end{array}$ & GIS certification programme \\
\hline United Kingdom & $\begin{array}{l}\text { Association of Geographic Information } \\
\text { (AGI), Royal Geographic Society (RGS) } \\
\text { and Royal Institution of Chartered } \\
\text { Surveyors (RICS-Geomatics) }\end{array}$ & $\begin{array}{c}\text { None that accommodates every GIS practitioner. RGS and RICS have } \\
\text { discipline specific certification programs that require relevant } \\
\text { membership, experience and CPD activity. }\end{array}$ \\
\hline Canada & $\begin{array}{l}\text { Canadian Institute of Geomatics (CIG), } \\
\text { with a chapter dedicated to GIS/LIS }\end{array}$ & $\begin{array}{l}\text { Certification program for Geomatics specialists (GIS/LIS). Requires } \\
\text { education to degree or diploma levels, } 6 \text { years relevant experience, } \\
\text { membership of CIG, references from } 4 \text { relevant professionals and } \\
\text { compliance with CIG code of ethics. Re-certification every } 5 \text { years. }\end{array}$ \\
\hline Australia \& New Zealand & $\begin{array}{l}\text { Geospatial Information \& Technology } \\
\text { Association (GITA) plus Surveying } \\
\text { and Spatial Sciences Institute (SSSI) }\end{array}$ & $\begin{array}{l}\text { GISP is recognized and GITA participation earns GISP points. } \\
\text { SSSI has a surveying-biased certification programme based on } \\
\text { educational qualifications and experience. }\end{array}$ \\
\hline Japan & GIS Association of Japan & $\begin{array}{l}\text { The GIS Association of Japan has an accreditation programme for } \\
\text { professionals and technical personnel. }\end{array}$ \\
\hline Nigeria & Nigerian Institution of Surveyors & $\begin{array}{l}\text { No programme for general GIS practitioners; some organizations } \\
\text { such as Nairaland offer Esri software specific certifications. }\end{array}$ \\
\hline South Africa & South African Geomatics Institute (SAGI) & $\begin{array}{l}\text { An examination based registration program by the South African } \\
\text { Council for Professional and Technologist Surveyors (PLATO). } \\
\text { No program for GIS professionals who are not surveyors. }\end{array}$ \\
\hline Germany & BVW, the German Association of Surveyors & No information \\
\hline China & $\begin{array}{l}\text { China Association of Geographic } \\
\text { Information Systems }\end{array}$ & No information \\
\hline India & Indian Society of Geomatics & No information \\
\hline
\end{tabular}

is in the process of integrating programs such as GISP with those of other countries and international organizations (e.g. the International Federation of Surveyors, the Open Geospatial Consortium, etc.) into an international standard for the certification of geoinformation professionals. So far, the ISO's Technical Committee TC 211 has produced a Technical Report TR/19122 on the issue, which is in circulation [16]. ISO TR/19122 recommends the setting up of an effective and feasible system for the qualification and certification of personnel in geographic information, to be advanced by a broad based international organization, which promotes the wide range of qualification and certification systems currently in place within individual countries. Such a system would support the national and international mobility of properly trained and educated personnel in the field of geographic information; This is also consistent with the International Federation of Surveyors (FIG) policy statement on the mutual recognition of professional qualifications [17].

\section{The Kenyan Situation}

\subsection{The Kenyan GIS Industry}

The Kenyan GIS industry started off, like in most of the world, in the mid 1980s, but in a very limited way. The few early GIS installations were at Government institutions (e.g. Department of Resource Surveys, Kenya Ag- ricultural Research Institute, etc.) and international organizations (e.g. United Nations Environmental Programme (UNEP), International Centre for Insect Physiology and Ecology (ICIPE), etc.). This has grown to over 100 installations today, mostly concentrated in and around the capital city Nairobi and covering all sectors including public, private, NGO and international organizations. With only 3 universities in the mid 1980s, there are now over 60 public and private universities and many of them offer GIS in some of their degree programmes; Consequently, there are today at least 3000 people trained in GIS at the professional and technician levels; There are many more who have basic awareness of GIS through short courses and on the job training [18-20]. The Kenyan GIS industry is therefore big enough to be experiencing the problems associated with lack of professional certification as described in Section 3.3.

\subsection{GIS Certification in Kenya}

A prerequisite for the setting up of a viable certification program is the presence of a strong professional association that brings together most practitioners from the geoinformation industry. Indeed, the scope of the ISO Technical Report referred to in Section 4.4 above is stated as, "... which describes a system for the qualification and certification by a central independent body of personnel in the field of Geographic Information...". 
Table 3. Previous attempts at setting up a national GIS professional association in Kenya.

\begin{tabular}{|c|c|c|c|}
\hline Association & Year Formed & Characteristics & Current Status \\
\hline GIS-KENYA & 2001 & $\begin{array}{c}\text { Formed with a broad base of geoinformation stakeholders and } \\
\text { much goodwill. Successfully hosted the Africa GIS conference } \\
\text { of } 2001 \text { in Nairobi. Thereafter, management problems saw it } \\
\text { falter; attempts to resuscitate it failed. }\end{array}$ & Moribund \\
\hline $\begin{array}{c}\text { ESRI-KUG } \\
\text { (ESRI-Kenya User Group) }\end{array}$ & 2004 & $\begin{array}{c}\text { Formed largely to bring together users of ESRI software. } \\
\text { Organized a number of local conferences, but lacked the } \\
\text { broad stakeholder base that would be needed to effectively } \\
\text { play the role of a national GIS association. }\end{array}$ & Largely inactive. \\
\hline $\begin{array}{l}\text { GISPAK (GIS Professional } \\
\text { Association of Kenya) }\end{array}$ & 2007 & $\begin{array}{c}\text { A spirited attempt by a number of GIS champions to re-actualize } \\
\text { the concept of a national GIS association with a limited } \\
\text { number of geoinformation stakeholders. }\end{array}$ & $\begin{array}{l}\text { Registered as a society } \\
\text { but inactive. }\end{array}$ \\
\hline ISK (GIS) & 2011 & $\begin{array}{l}\text { A new sub-chapter of the Institution of Surveyors of Kenya to } \\
\text { associate surveyors working in GIS. }\end{array}$ & $\begin{array}{l}\text { Still taking root but unlikely } \\
\text { to attract GIS stakeholders } \\
\text { outside surveying. }\end{array}$ \\
\hline
\end{tabular}

Looking at the Kenyan situation, one must say that while certification would be clearly a good thing, it would be putting the cart before the horse. A strong, professional association representing diverse geoinformation practitioners, which doesn't exist at present [21] needs to be established first, to unify the profession and develop uniform standards for certification. All previous attempts at setting up such an association, which are summarized in Table 3, have not yielded the desired result, hence the challenge remains.

The need for such an association is again strongly indicated by what has happened in the general computing industry in the country. Until the mid 80s, due to lack of standards and a professional body, all kinds of "computer colleges" issued all manner of certificates claiming competence in Ms Word, Excel, Access, Power Point, etc. The truth however was that many of the holders of these certificates were grossly incompetent in the use of these software packages. Since 1986 however, at least two professional associations have been formed, namely the Computer Society of Kenya (CSK) and The Information and Communication Technologies Association of Kenya (ICTAK); These have succeeded in turning the ICT industry around, with most ICT colleges now required to offer internationally recognized certification such as the Microsoft International Computer Driving License (ICDL) and certifications of the Institute for Management Information Systems (IMIS). The GIS industry in Kenya, and indeed in similar developing countries, therefore needs to move fast and form viable professional associations that can take charge of certification and related accreditation before the industry spins out of control.

\section{Conclusion}

This paper has defined GIS certification as a voluntary process through which suitably qualified and experienced individuals could be identified to the GIS consumer public by a professionally recognized competent body, with many attendant benefits. It notes that although such certification is the trend globally, it should preferably be preceded by the development of a certification standard that enjoys broad professional consensus, such as the GISCI program in the USA which is described in some detail, and which has a high potential of becoming a de-facto international standard for GIS certification. Such consensus can best be facilitated by a strong GIS professional association. A review of the Kenyan GIS industry shows numerous failed attempts at setting up a national GIS association, a clear indication that patience is needed in such efforts; Nevertheless, the paper encourages the revival of such efforts in Kenya and similar developing countries if their GIS industries are to eventually enjoy the benefits of GIS professional certification. Failure to do this, the paper warns, may result in the said GIS industries being flooded with meaningless certificates from sometimes dubious institutions.

\section{REFERENCES}

[1] P. A. Burrough, "Principles of Geographical Information Systems for Land Resources Assesment,” Oxford University Press, New York, 1986, 176 p.

[2] http://proceedings.esri.com/library/userconf/proc09/ucvid eos $/ \mathrm{htm} /$

[3] D. Di Biase, "Strengthening the GIS Profession," ArcNews, 2012.

[4] G. C. Mulaku, "The Concept of a Spatial Data Infrastructure: An African Perspective,” Geospatial Today, Vol. 1, No. 1, 2002, pp. 13-19.

[5] www.careeronestop.org/competencymodel/pyramid.aspx? $\mathrm{i}=\mathrm{Y}$

[6] T. W. Brush, "An Analysis of the Necessity for GIS Certification,” 2000. 
http://proceedings.esri.com/library/userconf/proc01/profe ssional/papers/pap279/p279.htm

[7] N. J. Obermeyer and H. J. Onsrud, "UCGIS White Paper on Accreditation and Certification for GIS,” 1997, 7 p.

[8] M. Goodchild and K. Kemp, "GIS Accreditation: What Are the Options?” ACSM Bulletin, 1992, pp. 44-47.

[9] ICCP, “Home Page of ICCP,” 1998. http://www.iccp.org/

[10] R. Chamard, "The ASPRS Program for Certification of Mapping Scientists," Proceedings of the ACSM/ASPRS Annual Convention and Exposition, Baltimore, Vol. 1, 1994, pp. 117-122.

[11] R. Chamard, "Certification of Photogrammetrist and Mapping Scientists," ACSM/ASPRS Annual Convention and Exposition Technical Papers, Bethesda, Vol. 2, 1995, pp. 154-159.

[12] M. Luccio, "GIS-The Greater Extent: GIS Professional Certification,” Professional Surveyor Magazine, 2007.

[13] GIS Certification Institute Website, 2004. http://www.gisci.org/

[14] S. Wilson, “Arc News,” 2011. www.esri.com/news/arcnews/spring11articles/tofc-spring 11.html
[15] K. McDonough, "What's in a Name?” Urisa News, No. 231, 2009, p. 5.

[16] ISO, "Technical Report TR 19122 on Geographic Information-Qualification and Certification of Personnel," 2002, $91 \mathrm{p}$.

[17] FIG, "Mutual Recognition of Professional Qualifications," FIG Publication No. 27, 2002, 28 p.

[18] G. C. Mulaku, J. B. K. Kiema and D. N. Siriba, "Assessment of Kenya's readiness for Geospatial Data Infrastructure Take off," Survey Review, Vol. 39, No. 306, 2007, pp. 328-337. doi:10.1179/175227007X197237

[19] Commission for Higher Education (Kenya), Information Booklet on the 10th Exhibition by Kenyan Universities, 2012, 218 p.

[20] G. C. Mulaku, "A Geospatial Database of Kenyan Universities,” Research Report, Department of Geospatial and Space Technology, University of Nairobi, Nairobi, 2013.

[21] G. C. Mulaku, "The Role of a Professional GIS Association in Kenya," Keynote Paper, The Kenya ESRI Supported GIS User Group Sympossium, University of Nairobi, Nairobi, 2004. 